\title{
Development of a Technology, Processing Carbon-containing Fine-grained Waste into High-quality Briquette Fuel
}

\author{
N.V. Toropova, A.V. Papin, and A.Yu. Ignatova \\ Kuzbass State Technical University, Kemerovo, Russia
}

Abstract

This article provides an overview of existing methods and techniques for processing man-made carbonaceous wastes from the coke chemical and coal mining industries, i.e. coke and coal dust. The advantages and disadvantages of the methods are briefly described. Based on the advantages, an oil agglomeration method was chosen to enrich the coke and coal dust. This method is effective in the enrichment of

Corresponding Author: N.V. Toropova

nadya.toropova.95@mail.ru

Received: 10 February 2018

Accepted: 14 April 2018

Published: 7 May 2018

Publishing services provided by Knowledge

(c) N.V. Toropova et al. This article is distributed under the

terms of the

Attribution License, which permits unrestricted use and redistribution provided that the original author and source are credited.

Selection and Peer-review under the responsibility of the RFYS Conference Committee. fine-grained waste, such as coal and coke dust, while the yield of the carbonaceous concentrate is up to $85 \%$. The results of the technical analysis of the initial carboncontaining wastes and the obtained coal concentrate are presented. The qualitative characteristics of the briquetted fuel obtained on the basis of the concentrate are given. The specifications of the briquetted fuel are presented and its advantages are described.

Keywords: coke and coal dust, oil agglomeration, low ash concentrate

\section{INTRODUCTION}

A new area in the development of coal processing technologies is associated with the creation of low-waste and waste-free industries, the utilization of environmentally polluting substances that are generated when coal is processed into industrial products.

Coal-mining and coal-consuming countries faced the 21st century in the context of the heightened environmental requirements and existing laws in certain countries. For example, those are the U.S. Clean Air Act issued in the early 1990s; The Kyoto Protocol on Measures against Climate Change and Global Warming ratified by the parliaments of most countries of the world; the new motor fuel quality standards in Europe [1].

One of the relevant issues for coal regions is that of the carbon-bearing finedispersed waste generation at coke-chemical and coal-mining enterprises. Coke and coal dust represent one of such wastes with particle sizes from o to $1 \mathrm{~mm}$. The wastes adversely affect the atmospheric air, water bodies, subsoil, flora, and fauna. 
In connection with the huge amount of carbonaceous wastes formed, it is necessary to identify waste processing techniques.

Thus, the average volume of coke dust formation at a coke-chemical plant is about $18,000-20,000$ tons a year. Coke dust is trapped in the aspiration systems of bins and coke transfer stations at coke-screening plants; it contains $12 \%-15 \%$ of water [2]; it is not used as fuel because of low heat output [3].

Coal mining is accompanied by the generation of a significant amount of various waste, up to $30 \%$ of the coal production. After production, coal is subjected to enrichment and sorting. Before coal is divided into fractions, dust and a fraction of less than $0.5 \mathrm{~mm}$ are washed out of the coal volume. The coal dust is generated during the following production operations, coal drawing by combines and blasting operations; coal loading by loading machines, transportation of coal by conveyors; when coal is enriched [4].

At present, there are various coke and coal dust processing methods and techniques. The waste processing efficiency can be ensured if physical and chemical methods of enrichment and briquetting are used.

The coke production waste, i.e. coke dust, can be used in metallurgy but it is not suitable for direct use thus requires special treatment. Therefore, many coke-chemical enterprises are tackling the coke dust formation problem, which in turn reduces the yield of the final product, coke, and increases air emissions.

For example, up-to-date coke plants use fully enclosed conveyor lines for coal supply, dust extraction during coal handling, dust collection during grinding and mixing with cleaning, emissions to the residual dust content $<20 \mathrm{mg} / \mathrm{m}^{3}$, wetting the surface of stacks with binding agents as well as a set of measures in operating coke-oven batteries as a result of which the residual dust content in the cleaned emissions should be less than $5 \mathrm{~g} / \mathrm{t}$ of coke [1].

The most common dust preparation methods are agglomeration which can be used for dust as a material for foaming the steelmaking slag and added to the coking charge, and briquetting.

Known is the 'hot' briquetting method for coal fines and dust with the use of binding components. The process takes place at a temperature of $400-520^{\circ} \mathrm{C}$ and a pressure of 20-80 MPa. Molasses, Portland cement, clay and gypsum are used as binders. Coal fines get into the crusher, after sufficient grinding, it passes through the auger conveyor into the mixer, where a homogeneous mass is created when the binders are added. After that, the ready-made mixture passes through the conveyor under the 
electromagnet. Then the mixture gets into the bunker and from there it is taken to the press machine, after which the finished product is dried and sent to the warehouse, or transported to a consumer [5].

Coal briquettes have several advantages, e.g. they are not toxic, and are convenient and ergonomic in the use of environmentally safe fuel; they are smokeless.

Clay, gypsum and lime as binders increase the ash content and reduce the specific heat of fuel [3]. However, is not economically sound to apply binders of the highest value that positively influence the quality of briquettes.

European countries, the advantages of the briquetted fuel have already been highly appreciated, and they produce briquettes based on coal fines in huge volumes and by various technologies. The fact is that in burning coal briquettes, the efficiency of the combustion facilities increases by $25-35 \%$ compared to burning raw coal, the particulate emissions with household gases are reduced by more than half, the sulphur dioxide emissions are reduced by $15-20 \%$, and fuel components are not to burn enough by $15-20 \%$.

Fine carbon-containing waste can be potentially disposed of in the form of watercoal fuel. So, coal-water fuel is known in the form of a suspension prepared by mixing solid powdered fuel, mainly low-calorie coal, with a liquid, water for supply to combustion devices at thermal power plants, in the metallurgical industry, in boiler plants and other heat-generating systems operating on liquid fuel $[6,7]$.

The Chinese University of Mining and Technology developed a technology for enriching fine coal classes in a cyclo-microbubble flotation column (CMFC) with a combination of cyclone separation and a flotation column equipped with an external generator of thin bubbles effectively depositing on the particle surfaces. The technology was successfully used to extract fine coal from sedimentation tanks during industrial tests. Coal particles up to $45 \mu \mathrm{m}$ were efficiently extracted. Laboratory and pilot tests demonstrated the possibility of producing a super pure product with an ash content of $1.5-1.6 \%$ from raw materials with an ash content of 9.8\% [8].

The disadvantages of coal-water fuel include a reduction of combustion heat by 900 $\mathrm{kJ} / \mathrm{kg}$ due to the additional amount of moisture compared to dry coal.

\subsection{Purpose of the research}

Development of a method for obtaining new products, a coal-coke concentrate from fine carbonaceous waste (coke and coal dust) and fuel briquettes based on it. 
According to the general goal, the following key issues were addressed in the research:

\section{Theoretical:}

- research into the physical and chemical properties of the raw material input (fine-dispersed waste) and the obtained coal concentrate;

- obtaining the briquetted fuel on the basis of coal concentrate and its quality examination.

\section{Practical:}

- to expand the raw material base for enterprises representing the energy and coke-chemical industries;

- to solve the carbonaceous waste accumulation and disposal problem by creating conditions for the development of industries for their processing and obtaining marketable products based on them;

- to develop a fine-dispersed carbonaceous waste disposal technology economically effective in the modern context.

\subsection{Scientific relevance of the research}

- A mechanism of the oil agglomeration of solid carbonaceous waste is established, and it is intensified by mixing the pulp with the gravitational forces to form an emulsion, which is explained by the equilibrium of the surface forces acting at the boundary of the phase separation (water-oil-solid carbon-containing waste);

- Achieved is a reduction in the total ash content and total sulphur content in solid carbonaceous wastes by removing from the mineral part of waste hydrophobic inorganic compounds;

- of the solid carbon-containing waste (coke and coal dust) obtained is a carbonaceous concentrate suitable for the coking technology and power engineering, with low ash content ( $\mathrm{A}^{d}=5.5 \%$ mas.) and low sulfur content $\left(\mathrm{S}^{d}{ }_{t}=0.2 \%\right.$ mas.);

- samples of the solid fuel briquettes with carbamide as a binder were produced based on the carbonaceous concentrate. 


\section{RESEARCH METHODS}

Fine-dispersed carbonaceous wastes (coke and coal dust) of Koks PJSC, Kemerovo were taken as targets of research. The research was carried out in the laboratory of multiphase system thermodynamics of the T.F. Gorbachev Kuzbass State Technical University named after. At the initial stage of the research, a technical analysis of the samples was carried out. The yield of volatile substances was determined according to the standards GOST 6382-2001 [9] and ash content according to GOST 11022-95 [10].

The data obtained are presented in Table. 1. As the result of the analysis, it was found that the carbonaceous wastes in question are referred to as medium-ash waste and are not suitable for direct use in processing technologies.

TABLE 1: Technical analysis of the carbon-containing waste.

\begin{tabular}{|c|c|c|c|c|c|}
\hline Item & $\mathrm{A}^{d}$, mas. $\%$ & $\mathrm{~W}^{a}$, mas. $\%$ & $\begin{array}{c}\mathrm{V}_{t}{ }^{d a f}, \text { mas. } \\
\%\end{array}$ & $\mathrm{~S}^{d}{ }_{t}$, mas. $\%$ & $\begin{array}{c}\mathrm{Q}_{s}{ }^{r}{ }^{\prime} \\
\mathrm{kcal} / \mathrm{kg}\end{array}$ \\
\hline Coke dust & 14.6 & 1.7 & 2.2 & 0.4 & 7,500 \\
\hline Coal dust & 20.4 & 1.8 & 20.9 & 0.4 & 6,350 \\
\hline
\end{tabular}

Then the waste was co-enriched thus resulting in a new product, coal concentrate.

The calorific value of the obtained concentrate was determined according to GOST 147-95 [11], the mass fraction of moisture determined according to GOST 11014-10981 [12] and sulphur was determined according to GOST 2059-95 [13].

To enrich the coke and coal dust, the oil agglomeration method was used, which makes it possible to separate the useful (organic) component of waste from the mineral part with the preparation of a low-ash high-calorific concentrate acceptable for coking and power engineering.

Enrichment was carried out in an experimental plant for the enrichment of fine waste. Used motor oil was used as a collector reagent.

\section{RESULTS AND DISCUSSION}

At the initial stage of the experiment, coke and coal dust were mixed at a ratio of 1:1 with water for 1-2 minutes using a paddle stirrer connected to the engine. Then, the used machine oil was added in the amount of $8.0-10.0 \%$ to the weight of the mixture of coke and coal dust and stirred for 5-8 minutes. 
At the output from the plant, a coal and coke concentrate with the characteristics shown in Table 2 was obtained. A coke-and-coal dust mixture in a 1:1 proportion makes it possible to achieve the acceptable heat of combustion of the finished concentrate, since the coke dust is a high-calorific waste and therefore the introduction of a depleting additive - coal dust - allows the use of coal concentrate for direct combustion in household furnaces without any burnt grates.

TABLE 2: Carbonaceous concentrate specifications.

\begin{tabular}{|c|c|c|c|c|}
\hline $\mathrm{A}^{d}$, mas. $\%$ & $\mathrm{~W}^{a}$, mas. $\%$ & $\mathrm{~V}_{t}{ }^{d a f}$, mas. $\%$ & $\mathrm{Q}_{s}{ }^{r}, \mathrm{kcal} / \mathrm{kg}$ & $\mathrm{S}^{d}{ }{ }$, mas. $\%$ \\
\hline 7.0 & 9.5 & 18.3 & 8,550 & 0.2
\end{tabular}

To ensure greater convenience in the transportation and use of carbonaceous concentrate, it is possible to make briquettes from it adding a binder. Carbamide was used as a binder in the amount of $8-10 \%$ to the weight of the initial raw material.

Carbamide choice is based on its availability due to its large production in the industry and low cost in the market. The binder (carbamide) consumption is determined by the need to form a strong fuel briquette [14].

Table 3 shows the technical characteristics of carbonaceous fuel briquettes. The mechanical strength at abrasion in the drum, compression and dropping were determined according to the standards GOST 18132-72 and GOST 21289-75 $[15,16]$.

TABLE 3: Carbonaceous fuel briquette specifications.

\begin{tabular}{|c|c|c|c|c|c|}
\hline \multicolumn{3}{|c|}{ Physical testing } & \multicolumn{3}{|c|}{ Fuel specifications } \\
\hline $\begin{array}{l}\text { compression, } \\
\mathrm{kg} / \mathrm{cm}^{2}\end{array}$ & $\begin{array}{c}\text { abrasion, } \% \\
\text { content of } \\
\text { pieces }>25 \mathrm{~mm} \\
\text { in size }\end{array}$ & $\begin{array}{l}\text { throwing off } \\
\text { (reduction), \% } \\
\text { content of } \\
\text { pieces }>25 \mathrm{~mm}\end{array}$ & $\begin{array}{c}\mathrm{A}^{d}, \text { mas. \% } \\
\text { (ash } \\
\text { content) }\end{array}$ & $\begin{array}{c}\mathrm{Q}_{s}{ }^{r}, \mathrm{kcal} / \mathrm{kg} \\
\text { (combustion } \\
\text { value) }\end{array}$ & $\begin{array}{l}\mathrm{S}^{d}{ }_{t,} \text { mas. \% } \\
\text { (sulphur } \\
\text { content) }\end{array}$ \\
\hline 70 & 94 & 94 & 5.0 & 8,600 & 0.2 \\
\hline
\end{tabular}

\section{CONCLUSION}

The conducted research identified the possibility of processing the coal and coke dust by enrichment and transformation into new innovative products: coal concentrate and solid fuel briquettes on its basis. The oil agglomeration is the most effective and comprehensive method of enrichment. The method makes it possible to significantly reduce the ash content of the feedstock, while the particle size of the coke and coal dust does not affect the process selectivity. 
The obtained coal briquettes are not inferior in quality to their analogues, which indicates the prospects and competitiveness of this kind of fuel.

Fuel briquettes can be used as a fuel for domestic and industrial purposes, while burning fuel briquettes (with the addition of carbamide) is environmentally safe. The introduction of this technology will improve the environmental situation in coalprocessing regions in view of reducing the amount of unused fine-grained waste.

\section{References}

[1] Цикарев Д.А., Петрова Г.И., Бычев М.И. Переработка углей. Часть І. Зарубежный научный и промышленный опыт / В.П. Зубков. - Якутск: ЯФ Издво CO PAH, 2005. - 128 c. (in English: Tsikarev D.A., Petrova G.I., Bychev M.I. Coal Processing. Part I. International Scientific and Industrial Experience / V.P. Zubkov. Yakutsk: YaF Publishing House of the Siberian Branch of the Russian Academy of Sciences, 2005. - 128 p.)

[2] Лотош В.Е. Л 804 Переработка отходов природопользования. Екатеринбург: Полиграфист, 2007. - C. 265. (in English: Lotosh V.E. L 804 Nature Management Waste Processing. Yekaterinburg: Polygraphist, 2007. - P. 265.)

[3] Брикетирование угля: технология, особенности и устройства для домашнего изготовления [Электронный ресурс]. (in English: Coal Briquetting: Home Production Technology, Features and Devices [Electronic resource]) http://teplowood.ru/briketirovanie-uglya.html

[4] Елишевич Т.А. Брикетирование угля со связующим. - М.: Недра, 1972. - 216 с. (in English: Elishevich T.A. Briquetting of Coal with a Binder. - Moscow: Nedra, 1972. 216 p.)

[5] Оборудование для брикетирования бурого и каменного угля [Электронный ресурс]. (in English: Liqnite and Coal Briquetting Equipment[Electronic source]) http://topbrik.ru.

[6] Водоугольное топливо на основе отходов обогащения угля коксохимических предприятий / Макаров А. С., Савицкий Д. П. // Журнал «Уголь» № 7 (999) 2009. C. 42-45. (in English: Water-Coal Fuel based on Coal Enrichment Waste by Coke Chemical Plants / Makarov A.S., Savitsky D.P. // Coal Journal No. 7 (999) - 2009. pp. 42-45.)

[7] Пат № 2173817 Топливная суспензия / Виноградов В. А., Доброхотов В. И., Мурко В. И., Нехороший И. Х., Своров В. А, Слепцов В. В. // Россия, 
опубл.: 25.12.2000. (in English: Path No 2173817 Fuel Suspension / Vinogradov V.A., Dobrokhotov V.I., Murko V.I., Nekhoroshy I.Kh., Svorov V.A., Sleptsov V.V. // Russia, published on 25 December 2000)

[8] Li B. et al. // Separation Science and Technol. - 2003. - V.38. - № 5. - P. 630-634.

[9] ГОСТ 6382-2001 Топливо твердое минеральное. Методы определения выхода летучих веществ. - М.: Изд-во стандартов, 2001. (in English: GOST 6382-2001 Solid Mineral Fuel. Methods for Determining the Yield of Volatile Substances. - Moscow: Publishing Standards, 2001.)

[10] ГОСТ 11022-95 Топливо твердое минеральное. Методы определения зольности. - М.: Изд-во стандартов, 1995. (in English: GOST 11022-95 Solid Mineral Fuel. Methods for Determining Ash Content. - Moscow: Publishing Standards, 1995)

[11] ГОСТ 147-95 Определение высшей теплоты сгорания и вычисление низшей теплоты сгорания. - М.: Изд-во стандартов, 1995. (in English: GOST 147-95 Determination of the Highest Heat of Combustion and Calculation of the Lowest Heat of Combustion. - Moscow: Publishing Standards, 1995)

[12] ГОСт 11014-2001 Угли бурые, каменные, антрацит и горючие сланцы. Ускоренный метод определения влаги. - М.: Изд-во стандартов, 2001. (in English: GOST 11014-2001 Lignites, Coals, Anthracite and Shale Coals. Accelerated Method for Determining Moisture. - Moscow: Publishing Standards, 2001)

[13] ГОСТ 2059-95 Топливо твердое минеральное. Метод определения общей серы сжиганием при высокой температуре. - М.: Изд-во стандартов, 1995. (in English: GOST 2059-95 Solid Mineral Fuel. Method for Determining Total Suphur by burning at High Temperature. - Moscow: Publishing Standards, 1995)

[14] Popov V., Papin A., Ignatova A., Makarovskikh A. Composite fuel based on residue from type and secondary polymer pyrolylis composite fuel based on residue from type and secondary polymer pyrolysis B сборнике: IOP Conference Series: Earth and Environmental Science 20. Cep. "XX International Scientific Symposium of Students, Postgraduates and Young Scientists on "Problems of Geology and Subsurface Development"'" 2016. C. 012065.

[15] ГОСТ 18132-72 Брикеты и полубрикеты торфяные. Метод определения механической прочности. - М.: Изд-во стандартов, 1972. (in English: GOST 1813272 Peat Briquettes and Semi-Briquettes. Method for Determining Mechanical Strength. - Moscow: Publishing Standards, 1972) 
[16] ГОСТ 21289-75 Брикеты угольные. Методы определения механической прочности. - М.: Изд-во стандартов, 1975. (in English: GOST 21289-75 Coal Briquettes. Methods for Determining Mechanical Srength. - Moscow: Publishing Standards, 1975) 